\title{
Kolektif Bellekte Antik Kentlerin İzi: Denizli Kenti Örneği
}

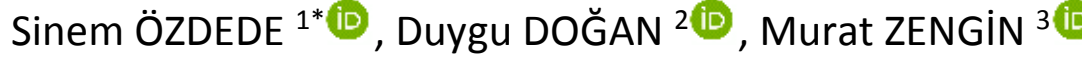 \\ ORCID 1: 0000-0002-6887-085X \\ ORCID 2: 0000-0002-0993-7647 \\ ORCID 3: 0000-0002-8528-7308 \\ ${ }^{1}$ Pamukkale Üniversitesi, Mimarlık ve Tasarım Fakültesi, Peyzaj Mimarlığı Bölümü, 20180, Denizli, Türkiye. \\ *e-mail: sinemozdede@pau.edu.tr
}

Öz

Kentler zaman içerisinde gerek doğal gerek sosyal olarak değişime uğrayan canlı yapılardır. Kentin yaşadığı her olay (savaşlar, yönetsel kararlar, deprem vb.), üzerindeki her iz kentte farklı katmanlar oluşturmaktadır. Kamusal alanlar bu katmanlarda geçmiş, bugün ve gelecek arasında kurulan ilişkilerin en kritik bağlayıcılarıdır. Çalışma kapsamında, bu kritik geçişin örneklerini yansıtabilecek, farklı tarihi doku örneklerini barındıran Denizli Kenti materyal olarak seçilmiştir. Bu bağlamda çalışmada kentin il sınırları içerisindeki antik kentlerin varlığının günümüz Denizli kentindeki kullanıcıların belleğindeki yeri, kent kimliği ve kamusal alanlardaki yansımaları irdelenmiştir. Çalışmada kısa-anket yöntemi uygulanmıştır. Yapılan ankette kent kullanıcılarının şehirleri ile en çok bağdaştırdıkları kelimeler üzerinden, kentlilik bilinci, kent algısı ve kentin doğal, kültürel, tarihi yapısının, kullanıc belleğindeki yeri sorgulanmıştır. Verilen cevaplar kelimelerin olumlu veya olumsuz anlamlarına göre sınıflandırılmıştır. Ayrıca kentin, kullanıcı izlenimlerine göre ne şekilde ön plana çıktığı sorgulanmıştır. Yapılan değerlendirmeler sonucu mevcut durum irdelenmiş, kolektif belleğin tasarım çalışmalarında kentsel kimliğinin oluşturulmasındaki önemi ortaya konulmuştur.

Anahtar Kelimeler: Kolektif bellek, kent kimliği, tarihi doku, antik kentler, Denizli

\section{Traces of Ancient Cities in Collective Memory: A Case Study of Denizli City}

\begin{abstract}
Cities are living structures that change over time both naturally and socially. Each event (wars, managerial decisions, earthquakes, etc.) experienced by the city, every trace on it creates different layers in the city. Public spaces are the most critical connectors of the relations established between the past, present and future in these layers. Within the scope of the study, the city of Denizli, which can reflect the examples of this critical transition and contains different historical texture samples, was chosen as the material. In this context, the place of the existence of ancient cities within the provincial borders of the city in the memory of the users in today's Denizli city, the urban identity and its reflections in public spaces were examined. The short-survey method was used in the study. In the survey, the urban consciousness, the perception of the city and the place of the natural, cultural and historical structure of the city in the user's memory were questioned through the words most associated with the city by the city users. The answers given were classified according to the positive or negative meanings of the words. In addition, it was questioned how the city came to the forefront according to user impressions. As a result of the evaluations, the current situation was examined and the importance of collective memory in establishing urban identity was revealed in design studies.
\end{abstract}

Keywords: Collective memory, urban identity, historical texture, ancient cities, Denizli

Citation / Atıf: Özdede, S., Doğan, D. and Zengin, M. (2021). Kolektif bellekte antik kentlerin izi: Denizli Kenti örneği. Journal of Architectural Sciences and Applications, 6 (2), 688-703.

DOI: https://doi.org/10.30785/mbud.100352 


\section{Giriş}

Şehirler canlı organizmalardır ve zaman içerisinde değişime uğramaktadırlar. Kuruldukları günden bu yana, genişleyerek, daralarak, zaman zaman yer değiştirerek inşa ve yıkım ile parça parça değişim göstermişlerdir (Hall, 2001; Tekkanat ve Türkmen, 2018). Bu değişimi ve çok değişkenli bu süreçleri anlamak ancak çok disiplinli yaklaşımlarla mümkündür. Bu bağlamda coğrafyacılar, arkeologlar, peyzaj mimarları, plancılar, mimarlar ve daha pek çok meslek disiplini kentsel değişim süreçlerini ayrıntılı analiz etmeye ve onu çok yönlü olarak anlamaya çalışmaktadır.

Kentlerin önemli özeliklerinden biri de değişmekte olan dönemlere uyum sağlamalarıdır. Süreç içerisindeki bu değişim son derece doğal olup aynı zamanda olması gerekendir. Fakat ileriye yönelik uyum süreçleri sırasında geçmiş ile olan bağları koparmak toplumun ortak bellek bütününde birtakım kırılmalar yaratmakta ve bunun sonucu olarak bir unutma döngüsü başlamaktadır (Aslan ve Kiper 2016; Mutlu, Tanriverdi Kaya ve Polat, 2019).

Bu bağlamda yapılan çalışmada, bellek kavramı, ortak belleğin nasıl oluştuğu ve bu süreçlerin kent kimliğine katkısı ve eksikliğinde hangi sorunların olabileceği ele alınmıştır. Ayrıca kolektif bellek kavramı üzerinden kent kimliği tespiti ve korunmasını, unutulan yerel örtük bilginin ve tarihsel değerlerin yeniden hatırlatılmasını amaçlamaktadır. Yapılan kısa anketler sonucu kolektif belleği oluşturan kentsel mekânları tespit etmek ve ortak hafızalarda yer alan bilgileri ortaya çıkarmak da çalışmanın sonuçlarında yer almaktadır.

\subsection{Bellek ve Kolektif Bellek}

“Bellek” kavramı, Türk Dil Kurumu'nun Büyük Türkçe Sözlüğ̈̈nde, “yaşananları, öğrenilen konuları, bunların geçmişle ilişkisini, bilinçli olarak zihinde saklama gücü, dağarcık, akıl, hafıza, zihin" olarak tanımlanmaktadır (TDK, 2020). Tanımdan anlaşılacağı üzere bellek, bir hatırlama ve unutma sürecidir. Hatırlama ve unutma ise bireyin ve toplumun kendini var etmesi ve varlığını sürdürmesinde önemli birer araçtır. Bu açıdan bakıldığında hatırlama ve unutmanın hiçbir zaman tarafsız olmayan (Pérouse, 2006) ve bilinçli olarak yapılan bu eylemin oldukça önemli anlamlar ve bilgiler içerdiği görülmektedir (Selvi Ünlü, 2017).

Sigmund Freud, bellek kavramını 'bireysel' olarak ele almıştır. Hatırlama ve unutma şekillerinin bellek ile doğrudan ilişkisinin olduğunu savunmuş ve bu iki kavramın tamamen kişisel bir durum olduğunu düşünmüştür. Ancak Halbwachs'a (1950) göre bellek, alt yapısı bireysel hatırlama veya uyarılmalardan meydana gelse de sonuçta sosyal bileşenlerden oluşmaktadır (Mutlu ve ark., 2019). Bu durumda 'Kolektif bellek' kavramı da ilk kez 1920'li yıllarda Fransız sosyolog Maurice Halbwachs tarafından ortaya atılmıştır. Halbwachs'ın geliştirdiği bu kavram; bireysel belleğin, çevreden dolayısıyla sosyokültürel bağlamlardan ayrı düşünülemeyeceği, bu sebeple bireylerin belleklerinin toplumsal etkilerden bağımsız olmayıp, sosyal çevre tarafından şekillendirildiği öngörüsüne dayanmaktadır. Bu kavramın geliştirildiği zamanlarda sanat tarihçisi Aby Warburg da 'toplumsal bellek' kavramını geliştirmiştir. İki kavramın ortak yönüne bakıldığında; belleği, biyolojik ve kişisel sınırlardan kurtarıp, sosyal sınırlar içerisine oturtmaları olduğu görülmektedir (Cuşa, 2013).

Boyer (1998); kolektif bellek bağlamında hatırlama ve unutmanın, gündelik pratiklerle ve yapılı çevre ile doğrudan ilişki içerisinde olduğunu anlatır. Aldo Rossi (1960) de, kolektif bellek tanımlarında "mimarlık ve kenti oluşturan her türlü değer ile ortak birliktelik" olduğunu vurgular ve kentin kendisinin orada yaşayanların kolektif belleği olduğunu belirtir (Çalak, 2012). Bu bağlamda, genellikle "hafıza", "kimlik" ve "yenilenmenin bütünleşmesinin" doğrusal bir şekilde işlediği varsayılır. Bellek, genellikle grup etkileşimleri ve yerinde kolektif belleğe odaklanan hatırlama eylemleri yoluyla canlı tutulan ortak bir kimlik altında insanları birbirine bağlayan kolektif bir varlık haline gelir (Othman, Nishimura ve Kubota, 2013).

Kolektif belleğin var olması için "yer" ile ilişki kurulması gerekmektedir. Bu bağlamda ortaya konmuş tüm semboller mekânların somutlaştııılması ve ortak kimliğin korunmasını sağlamaktadır (Çelen Öztürk, 2016; Mutlu ve diğerleri, 2019). 
Kolektif belleğin zedelenmesi mekân duygusunun yitirilmesine, aidiyet ve topluluk duygularının zayıflamasına ve bunların sonucunda yer kimliğinin kaybolmasına neden olmaktadır. Bu da bireysel ve sağlıksız toplumlar anlamına gelir (Mutlu ve diğerleri, 2019).

\subsection{Kent Kimliği}

Kimlik, bir varlığı diğer varlıklardan ayrılan özellikleri, kendine özgü olma durumu olarak ifade edilmektedir. Bir yere ait kimlikten söz edildiğinfde ise Proshansky (1978); "Insanın doğal ve yapılandırılmış çevreyle, fiziksel dünyayla ve başka insanlarla ilişkilerinde tercihleri, beklentileri, duyguları, değerleri ve inançları tarafından belirlenen, yerin ve kişinin kimliğini yapısında birleştiren karmaşık bir örüntü" olarak ifade etmiştir (Göregenli, 2010).

Tekeli (1991) ise, bir kentin kimliğini, orada yaşayanların kentte buldukları değerler kümesi olarak ifade etmektedir. Günümüze gelindiğinde kentin kimliği, fiziki çevre değil, toplumsal kimlik üzerinden okunmaktadır (Lalli, 1992; Perry ve Liggett, 1995; Kaypak, 2010) ve bu iki kimlik karşılıklı olarak birbirini etkilemektedir (Erdoğan ve Çorbacıoğlu Akay, 2018).

Kent kimliğinin üç temel elemanı bulunmaktadır (Aly, 2011). Fiziki ortam, aktiviteler ve anlam kent kimliğini oluşturan bileşenlerdir (Şekil 1). Burada mimari yapı, kentin kurulduğu çevre, çevresel planlama gibi öğeler fiziki ortamı oluştururken; festivaller, fuarlar gibi öğeler aktiviteleri, söz konusu fiziki ortam ve aktivitelere yüklenen mana da anlamı ifade etmektedir (Belge, 2018).

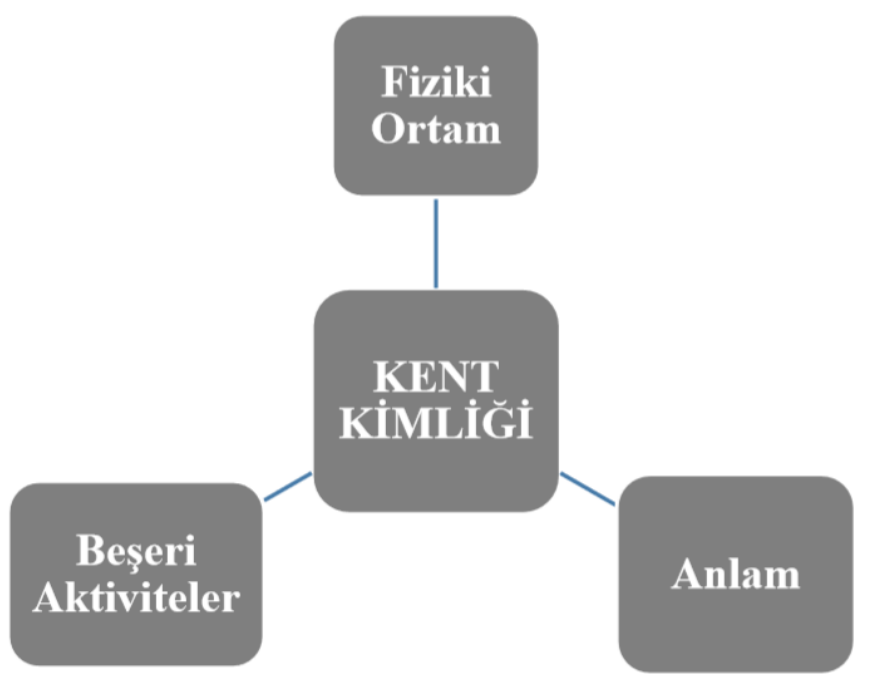

Şekil 1. Kent kimliğini oluşturan elemanlar (Aly, 2011; Belge, 2018)

Bir kentin kimliğinin şekillenmesi uzun sürelerde gerçekleşmektedir. Tarihi, coğrafyası, kültürel değerleri, insanı, mimarisi, içinde barındırdığı uygarlıkları, gelenekleri, yaşam şekli, ilk yerleşimden bugüne kadar geçirdiği tüm evreler kent kimliğinin bileşenleridir. Bunların yanı sıra, yeryüzü şekilleri, jeopolitik konumu, flora ve faunası, iklimi, Doğu-Batı kenti olması, deniz ve karayolu bağlantısı, başka kültürlere olan açıklığı-kapalıığı, ekonomik, sosyal ve doğal yapısı, geçirdiği işgaller ve savaşlar ya da depremler gibi kentin fiziksel özelliklerinden, tarihi ve kültürel miraslarından doğan etkenlerle bir kentin kimliği tanımlanabilir. Bu özelliklerin farklılaşması kentlerdeki özgün karakteri oluşturmaktadır (Turan ve Yalçıner Ercoşkun, 2017).

Lynch (1960) bir kentin kimliğini; kentin doğal, kültürel, ekonomik ve yapılı çevresinin mekânsal öğeleri ile bir bütün olarak değerlendirilmesi gerektiğini belirtmiştir. Buna göre, kent kimliği bileşenleri, aşağıdaki gibi sınıflandırılmıştır (Şekil 2). 


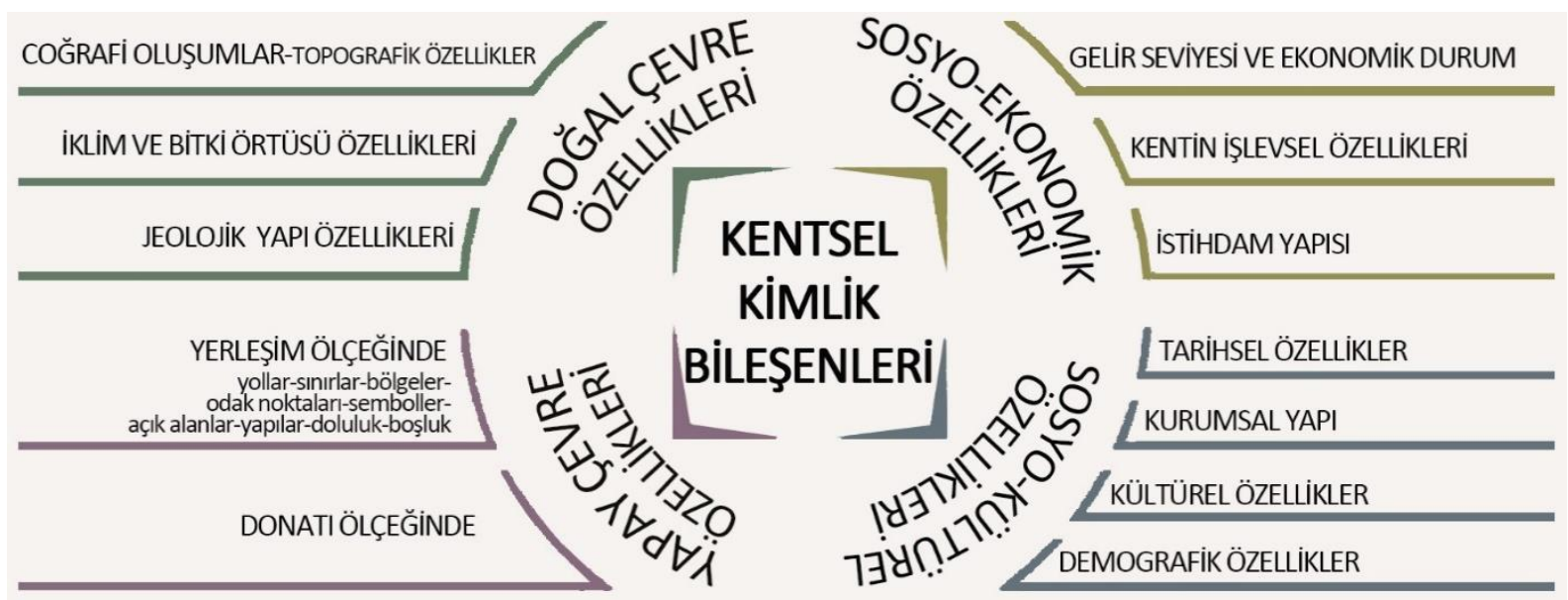

Şekil 2. Kentsel kimlik bileşenleri (Topçu 2011'den değiştirilerek)

Kentsel kimlik temelde kentin hangi özelliklere sahip olduğundan çok, kent kullanıcılarının o kenti nasıl algıladığının bir sonucudur. Kentin sahip olduğu mimari ve işlevsel donanımlar ne olursa olsun, insanların algısı, kimliğin en önemli belirleyicilerindendir (Çöl, 1998; Sağlık ve Kelkit, 2019). Calvino (1972) "Görünmez kentler" adlı kitabında "Bir kentte hayran kaldığın şey, onun yedi ya da yetmiş harikası değil, senin ona sorduğun bir soruya verdiği yanıttır" söylemi ile kent kimliğinde kullanıcı atfının önemine dikkat çekmiştir.

\subsection{Tarihi Peyzajlarda Kentsel Bellek ve Kimlik}

Aldo Rossi (1960) "Şehrin mimarisi" adlı kitabında şehrin, gündelik hayatın merkezi olmasının yanı sıra kolektif hafızanın da merkezi olduğunu savunur. Yani kentin kendisi ve içerisinde barındırdığı her öge orada yaşayanların kolektif belleğini oluşturur. Yaşanılan yerin, zamanla içerisinde biriktirdikleri ise onun anlamını ve ruhunu oluşturmaktadır. Bellek kavramı bu ölçekte ele alındığında, mekânın yaşadığı dönüşümlere bağlı olarak topluma yansımaları gerçekleşecektir. Kentteki değişim/dönüşüm; savaşlar, göçler, yönetsel kararlar vb. antropojenik nedenler olabildiği gibi; deprem, sel, yangın vb. doğal nedenlerden de kaynaklanabilmektedir. Böylece kentin yaşadığı her olay, üzerindeki her iz, kentte farklı katmanlar oluşturmaktadır. Bu katmanları anlamak, mekânı ve dolayısı ile kolektif belleği anlayabilmeyi kolaylaştırmaktadır.

Kentler belirli bir mekânda zaman içinde katmanlaşarak oluşmaktadır. Bu bağlamda zaman ve mekân kavramı, kentin tarihi sürekliliğinin sağlanmasında ve kentin günümüzdeki durumuna gelmesinde rol oynamaktadır. Tarihi kent alanları geçmişin bir kanıtıdır ve bu bölgelerdeki süreklilik kentsel bellek için önemlidir (Saylan, 2016). Kentte oluşan kolektif belleğin sürekliliği, o kentin kimliğinin, tarihinin ve yaşam tarzı olan sosyal olgunun yitirilmemesi açısından önemlidir. Kent belleğinin sürekliliğinin sağlanması için; tarihinin bilinmesi ve korunması, kentin her anlamda deneyimlenmesi ve kentin güncel durumunun farkında olunması gerekmektedir (Saylan, 2016; Kısakürek ve Bayazıt 2021).

\section{Materyal ve Yöntem}

\section{1. Çalışma Alanı}

Kentin çok değişken yapılarının olduğu bilinmektedir. Türkiye'de bu değişim, farklı ölçeklerde ve farklı şekillerde yaşanmaktadır. Kentlerde 1950'li yıllardan sonra başlayan değişim, zengin kültürel mirasa sahip Denizli kentinde de 50'li yıllarda başlamış (Avşar, 2014), 1980 sonrası daha baskın hale gelmiş ve kültürel miras yok olmaya başlamıştır (Erdoğan ve Akay Çorbacıoğlu, 2018). Bu bağlamda çalışma alanı seçilirken; Türkiye'de doğal ve kültürel peyzaj elemanları ile ön plana çıkan, tarihi özellikleri, konumu ve pek çok açıdan "en" leri oluşturan yapısı ile Denizli Kenti materyal olarak seçilmiştir.

Denizli bir kavşak noktası özelliği taşımaktadır. Tarihsel süreçte İpekyolu güncel olarak Ankara-Antalyaİzmir bağlantılarının merkezinde yer almaktadır. İçinde bulunduğu konum tarih boyunca ticaret için elverişli olmuştur. Bu durum, Denizli'yi üretim yapmak ve üretimin sürekliliği ve ürünleri piyasaya ulaştırmak için elverişli kılmıştır (Uçman Altınışık, 2017). 
Ege Bölgesinde yer alan ve tekstil-sanayi kenti olarak bilinen Denizli, aynı zamanda antik kentler bölgesidir. Bölge 798.75 km²olup, rakımı 350 m ve nüfusu 638.989'dur (Anonim, 2019). Kentin sembolü ise horoz ile özdeşleşmiştir.

Kevin Lynch "The Image of The City [Kent İmgesi]"nde kent kimliğini "benzerliklerden çok farklılıklara odaklanan bir toplum-mekânsal zemin" olarak nitelendirir. Bu bakış açısıyla değerlendirildiğinde Denizli'deki güncel kentsel yaşamın fark yaratan önemli kaynakları arasında bu arkeolojik ve endüstriyel olanaklar gelmektedir (Uçman Altınışık, 2017).

İ Kültür ve Turizm Müdürlüğü verilerine göre, il genelinde yer alan antik kentler (Şekil 3); Hierapolis (UNESCO Dünya Mirası Listesi); Laodikeia ile Tripolis (UNESCO Geçici Dünya Mirası Listesi), Colossae, Apollon-Leirbenos, Tabae, Eumenia, Herakleia-Salbace, Dionysopolis, Attuda, Apollonia-Salbace, Sebastopolis, Lounda, Trapezapolis, Attyochorium, Mossyna, Motello, Sala ve Aetos antik kentleridir (Anonim, 2017; Zengin, 2017). Bunun yanı sıra Denizli ilinde 19 antik kent ile 55 arkeolojik ve doğal sit (Kaleiçi, Laodikeia, Tripolis, Colossae, Sebastapolis, Apollonia, Hareklia, Eumenia, Dionyzopolis ve Hieropolis) yer almaktadır (Zengin, 2017). Milattan önceki yüzyıllara dayanan geçmişi, Denizli ve çevresindeki insan varlığının tarih öncesi devirlere kadar uzandığını göstermektedir.

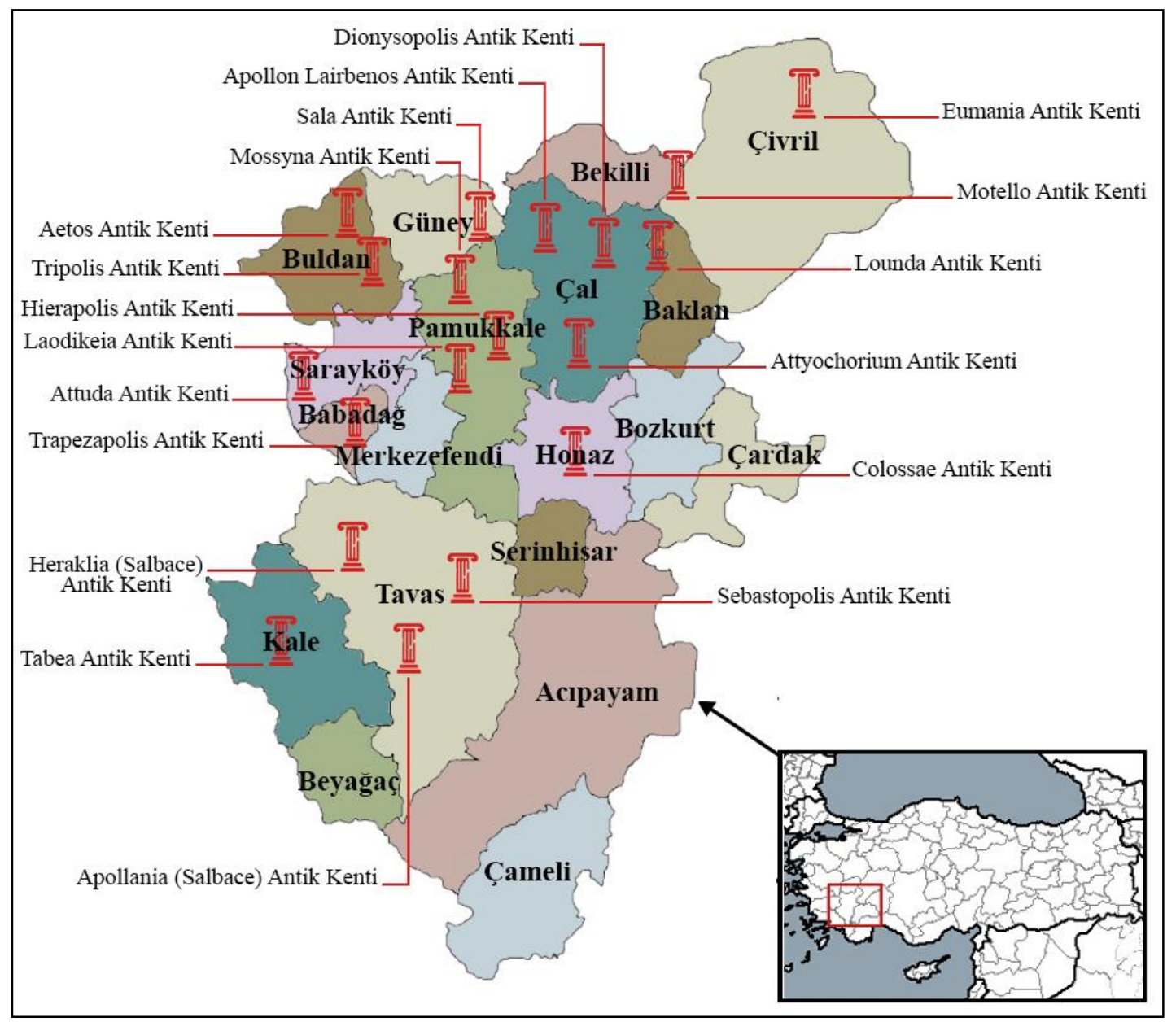

Şekil 3. Denizli Kenti konumu ve antik kentleri (Anonim 2020a'dan değiş̧irilerek)

Pamukkale Hierapolis Antik Kenti, Roma İmparatorluğu'nun da yüzyıllar boyu, termal kaynakları ile en önemli sağlık kentlerinden birisi olmuştur. Bunun yanı sıra Laodikya Antik Kenti ise; Suriye yolu üzerinde kurulduğu düşünülen ticaret ve tekstiliyle ünlü, zengin ve önemli kentlerinden birisi olarak bilinmektedir (Halaç, Yıldırım ve Kalak, 2018; Erdoğan ve Akay Çorbacıoğlu, 2018). Denizli Kenti aslında antik dönemin önemli şehirlerinden olan Laodikya'nın bir mirasçısı olarak kurulmuştur. Laodikya, Roma döneminde gelişmiş bir şehirdir ve Bizans İmparatorluğu'nun son dönemlerinde canlılığını kaybetmiştir. 12. yüzyılın sonlarında da Türkler (Selçuklular) bu bölgeye gelmiş ve harap olmuş bir yerleşim ile karşılaşmışlardır. Böylece doğudan gelen Türk nüfusu, Laodikya'nın yıkımı nedeniyle, günümüz Denizli kentinin olduğu yere kurulmaya başlamıştır (Baykara, 1994; Belge, 2018). 
Modern Denizli kentinin tarihi de antik döneme dayanmaktadır. 11. yüzyıl ile birlikte Kaleiçi bölgesine yerleşilmeye başlanmış, Ladik ve Lazıkıyye isimleri ile anılmıştır. Kentin askeri kısmı ise 15. yüzyıldan sonra etkisini yitirmiş, ticari alanlar artmış ve 1950-1960'lı yıllara kadar devam etmiştir (Halaç, Yıldııım ve Kalak, 2018; Erdoğan ve Akay Çorbacıoğlu, 2018). Tarihi kaynaklarda "suyun bol olduğu bahçelik bir yerleşme" olarak geçmektedir (Baykara, 1994; Belge, 2018).

Bölge halkının Rum kökenli olduğu ve tekstille uğraştığı bilinmektedir. Ayrıca ürünlerinin Anadolu'ya ulaştırılan en önemli merkezlerden biri olduğu (Savaş Yavuzçehre, 2010) çeşitli kaynaklarda yer almaktadır. Osmanlı İmparatorluğu zamanına kadar Ataoğulları, Germiyanoğulları, İnançoğulları Beyliği'nin yönetim merkezi olarak stratejik önemini korumuştur (Erdoğan ve Çorbacıoğlu Akay, 2018).

Denizli Kenti 20. yüzyıla temel ekonomik etkinliği tarım ve dokumacılığa dayanan küçük bir Anadolu kenti olarak girmiştir. Cumhuriyetin ilanından günümüze kadar olan sürede ise kent pek çok anlamda değişmiştir. Cumhuriyetin ilk yıllarında da Denizli'de halk, geçimini tarım ve dokumacılıktan sağlamaktaydı. 1950'lerde kırsal yörelerdeki ekonomik canlanmayla toplum yapısındaki değişmeler devam etmiştir. Tarım toplumundan sanayi toplumuna doğru bir gelişme söz konusudur. Ulaşım olanaklarının artmasıyla, büyük kentlerle ve özellikle İzmir ile kurulan ilişkiler, toplumsal yaşama yeni boyutlar getirmiştir. Bu dönemde başlayan kırdan kente göç giderek hızlanmıştır (Anonim, 2020b).

Denizli'nin gelişiminde ve kent kimliğinin oluşmasında sanayileşmenin önemli katkısı olmuştur. 2004 yılında yayımlanan "Kentler ve İmgeler" adlı eserde, Denizli'nin simgesi olarak 'horoz' yerine 'Buldan dokumacılığı' ve 'el işleri' gösterilmiştir. Bu da Denizli sanayisinin kent için ne kadar önem teşkil ettiğinin bir göstergesi niteliğindedir (Oğuz ve Özkan, 2004; Savaş Yavuzçehre, 2016).

1973 sonrası Denizli'nin “Kalkınmada Öncelikli Yöreler" kapsamında değerlendirilmesi ve teşviklerden faydalanması sanayileşmenin gelişmesine, ulaşım güzergahları üzerinde fabrikaların artmasına, ihracatın artmasına, kentin yoğun göç almasına neden olmuştur. Bu durum ise kentte büyük dönüşümlere neden olmuştur. Denizli 1980 sonrası liberal ekonomi politikalarının etkisinde kalmış, 1990 'lı yıllarda ise küreselleşmenin etkilerini hissetmeye başlamıştır. Küresel üretim zincirlerinde tekstil ve mermer sektörü ile yerini alan kentte sanayileşmenin mekânda yayılması, hizmet ve ticaret sektörlerindeki gelişmeler kentsel mekânı yoğun etkileyen faktörler olmuştur (Savaş Yavuzçehre, 2013; Savaş Yavuzçehre, 2016).

\section{2. Çalışmanın Yöntemi}

Çalışmanın yöntemi; Bieling ve diğerleri (2014) tarafından Avrupa'nın farklı kentleri için hazırlanan çalışmanın değiştirilerek Denizli Kenti koşullarına uyarlanması ile oluşturulmuştur.

Çalışma kapsamında kısa-anket metodu uygulanmış ve Denizli kent nüfusu verileri alınarak (638.989), istatistiksel olarak örneklem büyüklüğü hesaplanmış ve 389 kişinin bu nüfus verilerine göre yeterli olduğu görülmüştür. Bu bağlamda anket kapsamında 389 katılımcıya yaşadıkları şehir ile en çok bağdaştırdıkları ilk 5 kelimeyi söylemeleri istenmiştir. Anketlerin bir kısmı yürüyüş parkurları, üniversite kampüsleri, parklar, otobüs durakları, sokak, cadde vb. açık alanlarda yapılmıştır. Bir kısmı ise yemeiçme alanları, kapalı spor salonları ve evlerde yapılmıştır. Görüşme süreleri 1 ila 10 dakika aralığındadır.

Verilen cevaplar kelimelerin olumlu veya olumsuz anlamlarına göre sınıflandırılmıştır. Ayrıca kentin, kullanıcı izlenimlerine göre ne şekilde ön plana çıktığı sorgulanmıştır. Bunlar; kentin herhangi bir aktivite türü olabildiği gibi, bir yemek adı, kamusal alan niteliği, insani özellikleri, kent simgesi, doğal ya da turizm özelliği taşıması, stres barındırması ya da sadece yaşanılan yer olması gibi kenti tanımlayan sıfat olmasına göre gruplandırılmıştır. Ayrıca yaşadıkları kentte var olan antik kentlerin ne kadarında bulundukları da sorgulanmıştır. Cevabı veren katıımının yaş, cinsiyet bilgileri, eğitim düzeyi vb. demografik verileri de değerlendirmeye alınmıştır.

Çalışmanın verileri IBM SPSS Statistics 22 yazııımı ile analiz edilmiş, her bir grup için sıklık ve yüzde değerleri belirtilmiş, çapraz tablolama ve ki kare analizi uygulanmıştır. 


\section{Bulgular ve Tartışma}

Çalışma alanı olarak belirlenen Denizli Kenti'nde anket uygulanan katılımcıların demografik özelliklerine ilişkin sıklık ve yüzde değerleri Çizelge 1'de yer almaktadır.

Anket toplam 389 kişi üzerinden gerçekleştirilmiştir. Çalışmaya katılanların \%57,1'i erkek, \%42,9'u kadındır. Katılımcıların yaş grubu dağılımına bakıldığında \%56,4'ünün 18-25 yaş aralığında olup en yüksek katılımcı grubu oluşturduğunu, \%16,8'inin 26-35 yaş aralığında, \%15,2'sinin 36-50 yaş aralığında, \%8,8' inin 51-70 yaş aralığında, \%2,8' inin ise 71 yaş üzerinde olduğu görülmektedir.

Meslek dağııımına bakıldığında \%41 oranında çalışan, \%7,5'inin çalışmayan, \%6,2'sinin emekli ve $\% 45,3^{\prime}$ ünün ise öğrenci olduğu görülmektedir. Çalışmada öğrenci yoğunluğu daha fazla görülse de seçilen katıımcıların uzun süredir Denizli' de yaşamaları ya da Denizlili olmaları şart koşularak daha bilinçli ve doğru sonuçlar almak esas alınmıştır.

Çizelge 1. Katılımcıların demografik özelliklerine ilişkin sıklık ve yüzde değerleri

\begin{tabular}{|c|c|c|c|c|c|c|c|}
\hline & & Frekans & Yüzde & & & Frekans & Yüzde \\
\hline \multirow{5}{*}{ Cinsiyet } & Kadın & 167 & 42,9 & \multirow{5}{*}{ Meslek } & Çalışmıyor & 29 & 7,5 \\
\hline & & & & & Çalışıyor & 160 & 41 \\
\hline & Erkek & 222 & 57,1 & & Öğrenci & 176 & 45,3 \\
\hline & \multirow{2}{*}{ Toplam } & \multirow{2}{*}{389} & \multirow{2}{*}{100,0} & & Emekli & 24 & 6,2 \\
\hline & & & & & Toplam & 389 & 100,0 \\
\hline \multirow{6}{*}{ Yaş } & $18-25$ & 219 & 56,4 & \multirow{6}{*}{$\begin{array}{l}\text { Eğitim } \\
\text { Düzeyi }\end{array}$} & ilk-Ortaokul & 53 & 13,6 \\
\hline & $26-35$ & 65 & 16,8 & & Lise & 63 & 16,2 \\
\hline & $36-50$ & 59 & 15,2 & & Ön lisans & 19 & 4,9 \\
\hline & $51-70$ & 34 & 8,8 & & Üniversite & 224 & 57,6 \\
\hline & 71 ve üzeri & 11 & 2,8 & & Lisans Üstü & 20 & 5,1 \\
\hline & Toplam & 388 & 100,0 & & Toplam & 379 & 97,4 \\
\hline
\end{tabular}

Katılımcıların memleketleri ve Denizli'de ne kadar süredir ikamet ettikleri, kenti okuyabilmeleri ve yorumlayabilmeleri açısından önemlidir. Bu bağlamda Çizelge 2'de katılımcıların \%52,7'sinin Denizlili olduğu, \%21,6'sının Denizli olmasa dahi Ege Bölgesinden olduğu ve \%25,7'sinin ise Türkiye'nin farklı bölgelerinden olduğu gözlemlenmiştir. Denizli'de kaç yıldır ikamet ettikleri sorusuna, $\% 58,5$ oranında katılımcı 10 yıl ve daha üzeri zamandır; \%27,2'si 2-5 yıl arası, \%9,4'ü 6-10 yıl arası ve \%5'i 0-1 yıl arası zaman diliminden beri bu kentte bulunduklarını aktarmışlardır.

Çizelge 2. Katılımcıların Denizli Kenti’nde yaşadıkları süre ve memleketlerine ilişkin sıklık ve yüzde değerleri

\begin{tabular}{llll}
\hline \multirow{3}{*}{ Memleket } & & Frekans & Yüzde \\
\cline { 2 - 4 } & Denizli & 205 & 52,7 \\
\cline { 2 - 4 } & Ege Bölgesi & 84 & 21,6 \\
\cline { 2 - 4 } & Diğer Bölgeler & 100 & 25,7 \\
\cline { 2 - 4 } & Toplam & 389 & 100 \\
\hline \multirow{3}{*}{$\begin{array}{l}\text { Kaç yıldır Denizli Kenti'nde } \\
\text { yaşadıkları }\end{array}$} & $0-1$ & 19 & 5 \\
\cline { 2 - 4 } & $2-5$ & 104 & 27,2 \\
\cline { 2 - 4 } & $6-10$ & 36 & 9,4 \\
\cline { 2 - 4 } & 10 yıl üzeri & 224 & 58,5 \\
\cline { 2 - 4 } & Toplam & 383 & 100 \\
\hline
\end{tabular}

Çalışma alanı olarak belirlenen Denizli kentinde katılımcıların yaşadıkları şehir ile en çok bağdaştırdıkları ilk beş kelimeye ilişkin verdikleri yanıtlar ise, Şekil 4'te yer almaktadır. Burada verilen oranlar katılımcıların verdikleri yanıtlardan elde edilen beş kelime kategorizasyonun birbirlerine göre oranlarını barındırmaktadır. Kullanıcıların ilk verdikleri kelime, akla ilk gelen kent simgesi haline gelmiş olan "horoz" imgesi olarak gözlemlenirken, "Pamukkale" beş kelime bütününde ele alındığında \%38,5 ile birinci sırada gelmektedir. Bu sırayı daha sonra horoz, çınar meydanı, tekstil vb. farklı ögeler takip etmektedir. Antik kentler yanıtı ise \%4,1 kullanıcı tarafından belirtilmiştir. Kullanıcıların kentleri ile en çok bağdaştırdıkları kelimeler arasında yol çalışmaları, trafik problemleri vb. sorunların kent kimliğinde 
çok daha önem teşkil eden ögelerin önüne geçmesi ise kullanıı memnuniyeti ile ilgili olumsuzlukları göstermektedir.

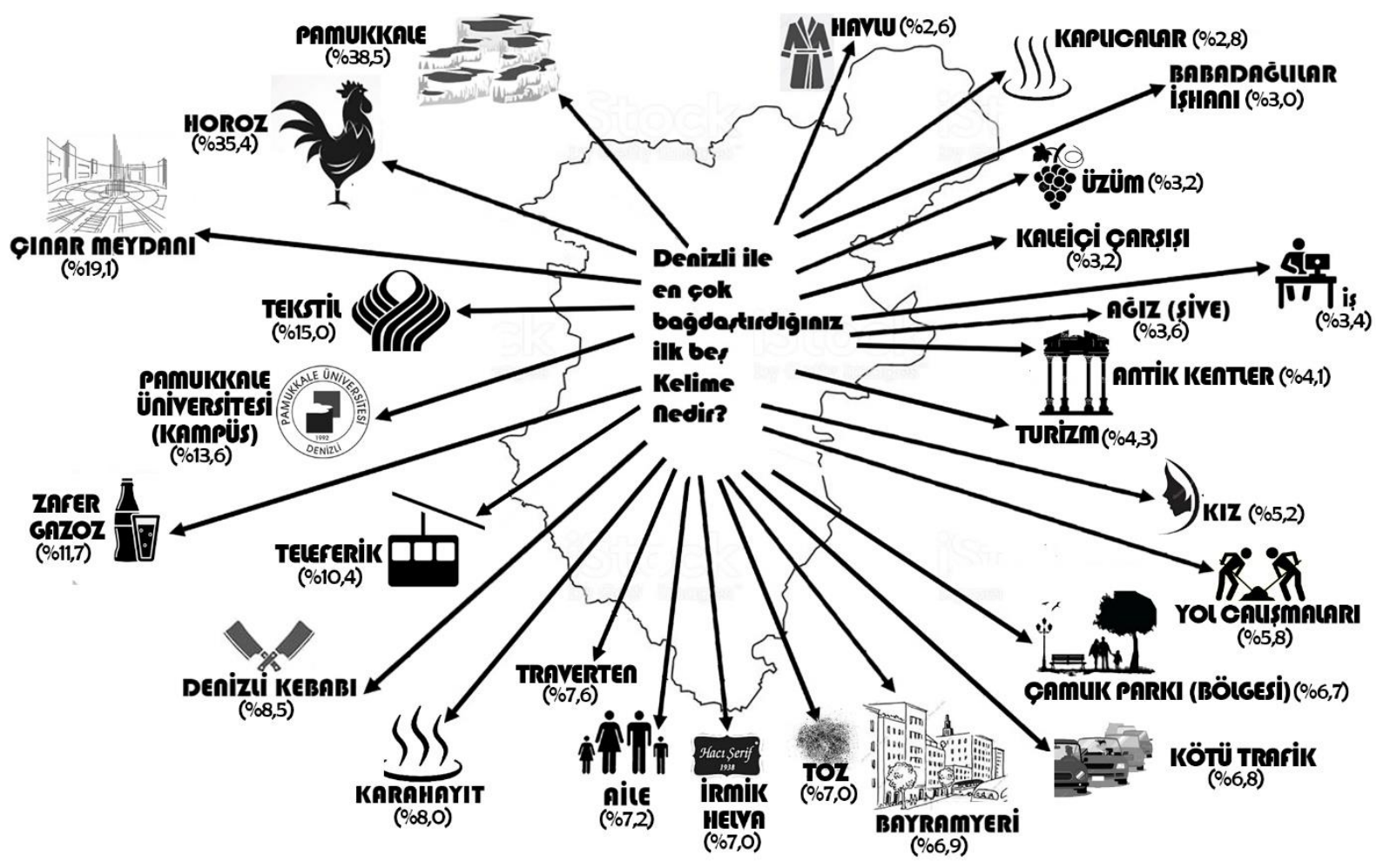

Şekil 4. Denizli kenti kullanıcılarının kentleri ile bağdaştırdıkları kelimeler

Denizli kentinde yaşayan katılımcıların yaşadıkları kente ilişkin aitlik duyguları Çizelge 3'te verilmiştir. Katılımcıların \%58,7'si kente ilişkin ait hissettiklerini ifade ederken, \%37,7'si ait hissetmemekte, \%3,8'i ise kısmen ait hissetmektedir.

Çizelge 3. Katılımcıların yaşadıkları kente duydukları aidiyete ilişkin sıkık ve yüzde değerleri

\begin{tabular}{|c|c|c|c|}
\hline & & Frekans & Yüzde \\
\hline \multirow{4}{*}{ Aidiyet } & Evet & 226 & 58,7 \\
\hline & Hayır & 146 & 38 \\
\hline & Kısmen & 13 & 3,5 \\
\hline & Toplam & 385 & 100,0 \\
\hline
\end{tabular}

Çoğunlukla aidiyet duygusunun yaşanılan kentte geçirilen süre ile ilişkili olduğu söylenmektedir. Bu çalışmada da ortalama 6 ve üzeri yıldır Denizli'de ikamet edenlerin oranına bakıldığında $(\% 9,4+\% 58,5$ Bkz. Çizelge 2) \%67,9 olarak ortaya çıkmaktadır. Ancak kente ilişkin aitlik duygusu sorulduğunda, ait hissedenlerin oranı $\% 58,7^{\prime}$ dir. Bu oranın daha yüksek olmamasının nedeni ise çok değişkenli bir tartışma konusudur. Bu durumda kentin, kullanıcısına olması gereken aidiyet duygusunu yeterince verememiş olduğu öngörüsü yanlış olmayacaktır.

Denizli Kenti kullanıcılarına yönlendirilen bir başka soru ise; bulundukları kentteki antik kent sayısıdır (Çizelge 4). Kullanıcıların \%35,5'i kentte sadece 1 adet antik kent olduğunu ifade ederken; \%31,1'i bilmediğini, \%2,5'i ise 10'dan fazla olduğunu belirtmiştir. 389 kişi üzerinden yalnız 2 kişinin 19 adet antik kent varlığını bildiği ortaya çıkmıştır. Bu anlamda kullanıcılar arasında yanlış bilgilendirmelerden ve eğitimsizlikten ileri gelen bilgi eksikliği mevcuttur. 
Çizelge 4. Katılımcıların yaşadıkları kentte yer alan antik kent sayısı sorusuna ilişkin sıklık ve yüzde değerleri

\begin{tabular}{|c|c|c|c|}
\hline & & Frekans & Yüzde \\
\hline \multirow{5}{*}{$\begin{array}{l}\text { Denizli Kenti'nde kaç adet antik } \\
\text { kent var? }\end{array}$} & Bilmiyorum & 114 & 29,3 \\
\hline & $1-3$ & 232 & 59,6 \\
\hline & $4-9$ & 34 & 8,7 \\
\hline & 10'dan fazla & 9 & 2,3 \\
\hline & Toplam & 389 & 100,0 \\
\hline
\end{tabular}

Antik kentlerde bulunma oranlarına bakıldığında ise; \%46,4 Pamukkale-Hierapolis'te daha önce bulunduklarını belirtirken, bu sayıyı \%26,8 ile Laodikya ve \%8 ile Tripolis takip devam ettirmektedir. Antik kentlerde hiç bulunmamış olanların sayısı ise $\% 13,6$ 'dır. Ayrıca $\% 3,5^{\prime}$ inin yanıtlarında Afrodisias Antik Kenti yer almaktadır. Aydın kentinde yer alan Afrodisias'ın bu kullanııılar tarafından Denizli kentinde olduğu bilinmektedir.

Antik kentlere ilişkin bir diğer soru; bölgede hangi medeniyetlerin var olduğuna ilişkin ya da kent içinde ve kent çevresinde bulunan antik kentlere ilişkin bir uygulama olup olmadığıdır. Katılımcılar kent içinde bu tip bir uygulama olmadığını belirtmişlerdir.

Kültür ve Turizm Bakanlığı (2018) tarafından yapılan bir çalışmada, 2017 yılının Denizli ziyaretçi sayılarına ilişkin bir istatistik çıkarılmış ve Laodikya Antik Kenti'nin çok ötesinde Hierapolis Antik Kenti turist sayısı çıkarılmışır. Aslında bu durum kullanıcı belleğinde de tam bu şekilde yer almakta, hatta bu çalışmada da çok önemli bir yüzde Denizli'de sadece 1 adet antik kent olduğunu ve onun da Hierapolis olduğunu iddia etmektedir.

Çizelge 5. 2017 yılında Denizli kentinde müze ve ören yerlerine ilişkin ziyaretçi sayıları (Kültür ve Turizm Bakanlığı, 2018)

\begin{tabular}{lll}
\hline Müze ve Ören Yerleri & Ziyaretçi sayısı & Yüzde \\
\hline Hierapolis (Pamukkale) Ören Yeri & 1.494 .893 & 90,0 \\
\hline Hierapolis (Pamukkale) Arkeoloji Müzesi & 123.290 & 7,4 \\
\hline Denizli Atatürk ve Etnografya Müzesi & 26.628 & 1,6 \\
\hline Laodikeia Antik Kenti & 16.612 & 1,0 \\
\hline Denizli (Toplam) & 1.661 .423 & 100 \\
\hline
\end{tabular}

Kullanıcılara kentte en çok vakit geçirilen alanlar sorulduğunda (Şekil 5), \%19,8'i ev, \%14,8'i Pamukkale Üniversitesi, \%9,6'sı kafeler, \%7,9'u Çınar Meydanı olarak sıralanmaktadır. Ev ve iş yerinin öncelikli sıralarda yer alması tahmin edilebilir bir durumdur. Pamukkale ilç̧esinde görüşmelerin yapılması üniversite cevaplarını artırmıştır. Ancak hemen sonrasında kafeler, meydan, AVM'ler sosyal hayatın kültürel hayatın önüne geçtiğinin göstergesi niteliğindedir. 


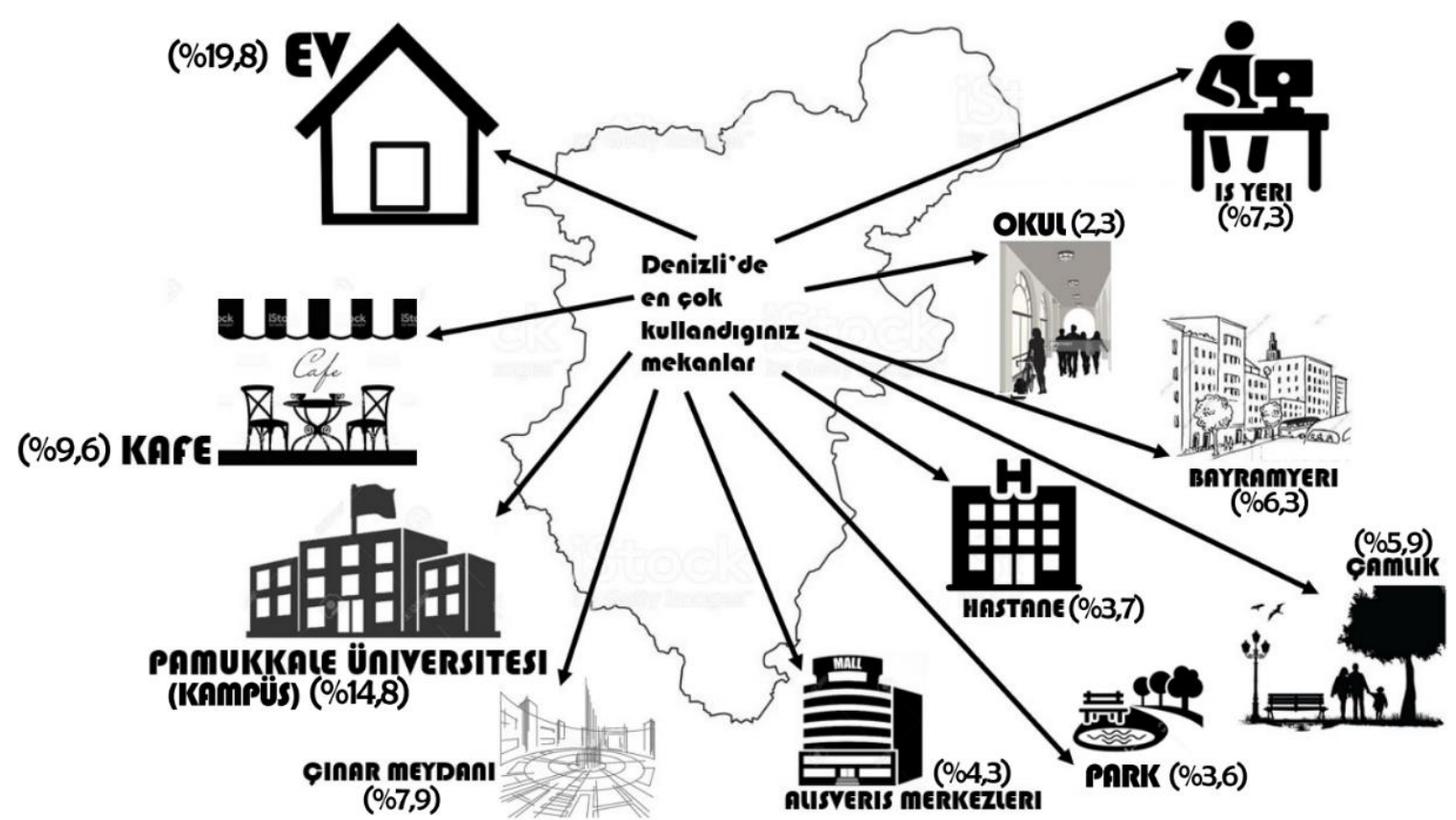

Şekil 5. Denizli kenti kullanıcılarının en çok kullandığı mekânlar

Çalışmada kullanıcıların Denizli ile en çok bağdaştırılan ilk beş kelimeye ilişkin verdikleri cevaplar, özelliklere göre kategorize edilmiştir. Verilen yanıtların gruplandırılmasında karar verilen 14 özellik (aidiyet, aktivite çeşidi, doğal yer, iklim, insani özellikler, kamusal alan, kent simgesi, stres-trafik, tarımsal ürün, turizm, tarihi yer, yemek adı, diğer), araştırma ekibinin verilen kelimeleri kategorize etmesi ile oluşturulmuştur.

Kullanıcıların ne kadar zamandır Denizli'de yaşadıkları ile gruplandırılan bu 13 özelliğin çapraz tablolarına bakıldığında, anlamlılık değerleri açısından anlam bulunamamıştır. Dolayısıyla Denizli'de doğup büyüyen bir kişinin bu kent ile bağdaştırmış olduğu kelimeler ile kentte 1 yıldır yaşayan kullanıcıların verdiği cevaplar arasında bir fark yoktur (Çizelge 6). Ancak aidiyet duygusunun kentte yaşanılan süre ile arttığı, aynı şekilde bölge insanının karakteristik özelliklerine de geçen süreçte alışıldığı bu çizelgede gözlemlenmektedir.

Çizelge 6. Katılımcıların kentte yaşadıkları yıl ile kente ilişkin bağdaştırılan kelime özellikleri arasındaki çapraz tablo, sıklık ve yüzde değerleri

\begin{tabular}{|c|c|c|c|c|c|c|c|c|c|}
\hline & & \multicolumn{8}{|c|}{ Denizli'de kaç yıldır yaşıyorsunuz? } \\
\hline & & \multicolumn{2}{|c|}{$0-1 y ı l$} & \multicolumn{2}{|l|}{ 2-5 yıl } & \multicolumn{2}{|l|}{ 6-10 yıl } & \multicolumn{2}{|c|}{10 yıl üzeri } \\
\hline & & & Yüzde & Frekans & Yüzde & Frekans & Yüzde & Frekans & Yüzde \\
\hline \multirow{13}{*}{$\begin{array}{l}\frac{\text { ত }}{\bar{y}} \\
\overline{\overline{\bar{d}}} \\
: 0\end{array}$} & Aidiyet & 0 & 0,0 & 6 & 5,8 & 3 & 8,3 & 26 & 11,7 \\
\hline & Aktivite & 1 & 5,3 & 7 & 6,7 & 1 & 2,8 & 14 & 6,3 \\
\hline & Diğer & 2 & 10,5 & 10 & 9,6 & 2 & 5,6 & 11 & 4,9 \\
\hline & Doğal yer & 4 & 21,1 & 11 & 10,6 & 1 & 2,8 & 17 & 7,6 \\
\hline & Iklim & 1 & 5,3 & 9 & 8,7 & 6 & 16,7 & 18 & 8,1 \\
\hline & İnsani özellikler & 0 & 0,0 & 10 & 9,6 & 6 & 16,7 & 38 & 17,0 \\
\hline & Kamusal alan & 8 & 42,1 & 38 & 36,5 & 18 & 50 & 65 & 29,1 \\
\hline & Kent simgesi & 11 & 57,9 & 63 & 60,6 & 28 & 77,8 & 126 & 56,5 \\
\hline & Stres-trafik & 6 & 31,6 & 48 & 46,2 & 13 & 36,1 & 89 & 39,9 \\
\hline & Tarımsal Ürün & 6 & 31,6 & 25 & 24,0 & 5 & 13,9 & 54 & 24,2 \\
\hline & Turizm & 8 & 42,1 & 30 & 28,8 & 9 & 25,0 & 78 & 35,0 \\
\hline & Tarihi yer & 3 & 15,8 & 4 & 3,8 & 4 & 11,1 & 22 & 9,9 \\
\hline & Yemek & 7 & 36,8 & 39 & 37,5 & 14 & 38,9 & 94 & 42,2 \\
\hline
\end{tabular}

Cinsiyet ve kent ile bağdaştırılan kelimeler arasında da (Çizelge 7) bir fark ortaya çıkmamıştır $(p=0,871)$. Böylece kullanıcının kadın veya erkek oluşu ile de cevaplarının etkilenmediği görülmektedir. 
Kullanıııların Denizlili ya da farklı kentlerden olmaları da cevaplarda anlamlı bir fark oluşturmamıştır $(p=0,490)$.

Çizelge 7. Katılımcıların Denizlili ya da diğer bölgelerden oluşu ve kent ile bağdaştıılan kelime özelliklerine ilişkin çapraz tablo, sıklık ve yüzde değerleri

\begin{tabular}{|c|c|c|c|c|c|c|c|c|c|}
\hline & & \multicolumn{4}{|c|}{ Memleket } & \multicolumn{4}{|l|}{ Cinsiyet } \\
\hline & & \multicolumn{2}{|l|}{ Denizli } & \multicolumn{2}{|l|}{ Diğer } & \multicolumn{2}{|l|}{ Erkek } & \multicolumn{2}{|l|}{ Kadın } \\
\hline & & Frekans & Yüzde & Frekans & Yüzde & Frekans & Yüzde & Frekans & Yüzde \\
\hline \multirow{13}{*}{ 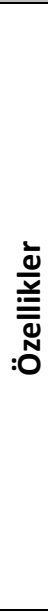 } & Aidiyet & 24 & 11,5 & 11 & 6,1 & 14 & 8,4 & 21 & 9,5 \\
\hline & Aktivite & 15 & 7,2 & 9 & 5,0 & 15 & 9,0 & 9 & 4,1 \\
\hline & Diğer & 12 & 5,8 & 13 & 7,2 & 11 & 6,6 & 14 & 6,3 \\
\hline & Doğal yer & 17 & 8,2 & 18 & 10,0 & 12 & 7,2 & 23 & 10,4 \\
\hline & iklim & 18 & 8,7 & 17 & 9,4 & 13 & 7,8 & 22 & 10,0 \\
\hline & İnsani özellikler & 35 & 16,8 & 20 & 11,1 & 20 & 12,0 & 35 & 15,8 \\
\hline & Kamusal alan & 63 & 13,9 & 28 & 15,6 & 58 & 34,7 & 71 & 32,1 \\
\hline & Kent simgesi & 125 & 60,1 & 108 & 60,0 & 98 & 58,7 & 135 & 61,1 \\
\hline & Stres-trafik & 82 & 39,4 & 77 & 42,8 & 69 & 41,3 & 90 & 40,7 \\
\hline & Tarımsal Ürün & 55 & 26,4 & 35 & 19,4 & 38 & 22,8 & 52 & 23,5 \\
\hline & Turizm & 67 & 32,2 & 59 & 32,8 & 54 & 32,3 & 72 & 32,6 \\
\hline & Tarihi yer & 21 & 10,1 & 13 & 7,2 & 15 & 9,0 & 19 & 8,6 \\
\hline & Yemek & 90 & 43,3 & 67 & 37,2 & 69 & 41,3 & 88 & 39,8 \\
\hline \multicolumn{4}{|c|}{$p=0,490(p>0,05$ fark yoktur) } & \multicolumn{6}{|c|}{$P=0,871(p>0,05$ fark yoktur $)$} \\
\hline
\end{tabular}

Katılımcıların yaşadıkları peyzaj ile bağdaştırdıkları 5 özelliğe ilişkin yanıtlarının kelime anlamlarının; olumlu, olumsuz ve nötr olarak değerlendirilmeleri ile aşağıda yer alan çizelgeler ortaya çıkmıştır (Çizelge 8-9). Burada nötr olarak değerlendirilen durum, genelde yer isimleri vb. olumlu ya da olumsuza ilişkin herhangi bir anlam oluşturmayan kelimelerdir.

Katılımcı yanıtlarının olumlu-olumsuz anlamlarının Denizlili olma durumuna göre, ya da kullanıcı cinsiyetlerine göre değişkenlik gösterip göstermediği ise Çizelge 8'de görülmektedir. Olumlu ve nötr ifadeler kullanıcının Denizlili olup olmayışına göre farklı bir frekans göstermez iken; Denizlili olmayan kişilerin kente ilişkin olumsuz kelimeleri $(\% 36,1)$ daha sık ifade ettiği gözlemlenmiştir. Benzer oranlar kadın kullanıcıların olumsuz yanıtları $(\% 35,6)$ ile erkek kullanıcıların $(\% 28,1)$ arasında da gözlemlenmiştir. Ancak genel anlamda bu çapraz tablolarda da anlamlılık gözlemlenmemiştir $(P>0.05)$.

Çizelge 8. Katılımcıların cinsiyetleri ve memleketlerinin, kenti değerlendirdikleri peyzaj özellikleri yanıtlarına ilişkin çapraz tablo, sıklık ve yüzde değerleri

\begin{tabular}{|c|c|c|c|c|c|c|c|c|c|}
\hline & & \multicolumn{4}{|l|}{ Cinsiyet } & \multicolumn{4}{|c|}{ Memleket } \\
\hline & & \multicolumn{2}{|l|}{ Erkek } & \multicolumn{2}{|l|}{ Kadın } & \multicolumn{2}{|l|}{ Denizli } & \multicolumn{2}{|l|}{ Diğer } \\
\hline & & Frekans & Yüzde & Frekans & Yüzde & Frekans & Yüzde & Frekans & Yüzde \\
\hline \multirow{3}{*}{$\begin{array}{l}\text { Katılımcı } \\
\text { yanıtları }\end{array}$} & Nötr & 74 & 44,3 & 95 & 42,8 & 95 & 45,5 & 74 & 41,1 \\
\hline & Olumlu & 165 & 98,8 & 220 & 99,1 & 207 & 99,0 & 178 & 98,9 \\
\hline & Olumsuz & 47 & 28,1 & 79 & 35,6 & 61 & 29,2 & 65 & 36,1 \\
\hline & \multicolumn{5}{|c|}{$\mathrm{P}=0,461$ (Fark yoktur) } & \multicolumn{4}{|c|}{$\mathrm{P}=0,41$ (Fark yoktur) } \\
\hline
\end{tabular}

Katılımcı yanıtlarının olumlu-olumsuz anlamlarının Denizli kentinde bulunma durumuna göre değişkenlik gösterip göstermediği ise Çizelge $9^{\prime}$ da görülmektedir. Aslında burada da aidiyet duygusu çizelgelerine benzer şekilde, kentte yaşanılan süre ilerledikçe, kente alışıldığı ve verilen olumsuz cümlelerin azaldığı gözlemlenebilmektedir. Bu bağlamda kentin sevilmesi ile kente duyulan aidiyetin farklı kavramlar olduğu söylenilebilir. Ayrıca Kutay Karaçor ve Köylü (2019) çalışmalarında bireylerin bir yere ilişkin bağlıı̆̆ının artmasının, fiziksel çevre kalitesi algılarının da artmasına yol açtığını belirtmişlerdir. 
Çizelge 9. Katılımcıların kentte bulunma durumları ve yaşadıkları peyzaj özelliklerine yanıtlarına ilişkin çapraz tablo, sıklık ve yüzde değerleri

\begin{tabular}{|c|c|c|c|c|c|c|c|c|c|}
\hline & & \multicolumn{8}{|c|}{ Kaç Yıldır Denizli'de siniz? } \\
\hline & & \multicolumn{2}{|l|}{$0-1$ yıl } & \multicolumn{2}{|l|}{ 2-5 yıl } & \multicolumn{2}{|l|}{ 6-10 yıl } & \multicolumn{2}{|c|}{10 yıl üzeri } \\
\hline & & Frekans & Yüzde & Frekans & Yüzde & Frekans & Yüzde & Frekans & Yüzde \\
\hline \multirow{3}{*}{$\begin{array}{l}\text { Katılımcı } \\
\text { yanıtları }\end{array}$} & Nötr & 9 & 47,4 & 48 & 46,2 & 18 & 50,0 & 93 & 41,5 \\
\hline & Olumlu & 19 & 100,0 & 104 & 100,0 & 36 & 100,0 & 220 & 98,2 \\
\hline & Olumsuz & 7 & 36,8 & 36 & 34,6 & 11 & 30,6 & 70 & 31,3 \\
\hline
\end{tabular}

Tarihi çevreler genellikle bulundukları yerleşimlerin merkezinde olduklarından içerisinde yer alan kültür ve tabiat varlıkları vb. değerler her dönemde toplumların ilgisini çekmiştir. İnsanoğlu kendinden önceki dönemlerin toplumlarını, yaşam biçimlerini ve bunların mekâna yansımalarını öğrenmeye her zaman meraklı olmuştur. Geçmişten günümüze gelen tarihi çevreler, toplumların zamanla cazibelerinin azalmasına ve buna bağlı olarak da toplumsal (kolektif) bellekteki yerinin zayıflamasına neden olmaktadır (Avcıoğlu 2016). Çalışma kapsamında yapılan anket Denizli kentinde yaşayanlar açısından da durumun bu şekilde olduğunu ortaya koymaktadır. Denizli ilinde bulunan 19 adet antik kentin $(\% 4,1)$ kent kimliğinde yeri neredeyse bulunmamaktadır. Aynı durum bir başka tarihi yapı olan kent merkezinde, söz konusu antik kentlere ilişkin hiçbir simgenin bulunmaması ya da çeşitli sebeplerle kent merkezinin bugünkü yerine taşınarak eski merkezin (Laodikya) uzağında kalması ve eski merkezle turizm sektörü haricinde hiçbir bağının bulunmaması kentlinin belleğinde diğer simgeler kadar yer edememiş ve kent kimliğinde de yerini bulamamasına neden olmuştur.

Erdoğan ve Akay Çorbacıoğlu (2018) Denizli bölgesi için yaptıkları çalışmada Kaleiçi/Bayramyeri Bölgesi kimliğinin; geçmişten gelen fiziksel, sosyal, kültürel, işlevsel özellikleri bakımından zengin olduğunu ancak sahip olduğu değerleri koruyamadığını ortaya koymuşlardır. Nitekim Denizlili Mimar Cengiz Bektaş (2007) da yaptığı çalışmalarda, Denizli kent merkezinin tanımsızlığına, yeşil dokunun yetersizliğine ve kentin kimliksiz bir beton yığını olduğuna, tarihi yapıların yoksunluğuna ve algılanmadığına, kent belleğinin zayıf olduğuna dikkat çekmiştir. Tarihi dokunun yok oluşunun, kentin kimliğinin ve belleğinin yok olmasına neden olduğunu da belirtmiştir. Bu çalışmada da benzer şekilde çok daha fazla potansiyel barındıran bu alanın kullanıcı belleğindeki yerinin \%3,2 olması değerlerinin korunamaması yanı sıra bellekteki yerini de gün be gün yitirdiğini göstermektedir. Kaleiçi bölgesi gerek yerel yönetimlerin gerekse Denizli halkının canlandırması gereken hafıza mekânları arasındadır.

Bu bağlamda Denizli ilinde bulunan antik kent ve diğer tarihi peyzajlarla kent kimliğinin özdeşleşmesi ve bu alanların gelecek nesillere "anlamını kaybetmeden" aktarılıp korunması gerekli ve önemlidir.

Yapılan kısa anketlerde; uzun yıllardır bu kentte olan kullanıcılar, 1973 sonrası “Denizli'nin Kalkınmada Öncelikli Yöreler" kapsamında teşviklerden faydalanmasından sonra önemli bir zenginleşmeden bahsetmektedirler. Aslında bu ekonomik kalkınma süreci Denizli Kenti'ne olan göçleri artırmış ve bu sosyal düzen değişimi kentin algılanış biçimini de değiştirmiştir. Örneğin Oğuz ve Özkan (2004)'ın yaptığı çalışmada Denizli Kenti simgesini horoz yerine, Buldan dokumacılığı ve el işleri olarak bulmuşlardır. Bu durum, zaman içerisinde kentsel simgelerin değişebileceği durumuna bir örnek teşkil etmektedir. $O$ halde tarihi bilgilerin tekrar önemsendiği bir platform oluşturulduğunda, halkın bilinçlendirilmesi sonucu ile eski bellekte yer alan ögeler günümüz belleğine taşınabilecektir.

\section{Sonuç ve Öneriler}

Kentsel kimlik oluşumunun kolektif bellekte yer alan ögelerin sonucu oluştuğunu ve kente ilişkin geliştirilen aidiyet duygusunun temeli olduğu bilinmektedir. Bu çalışmada ortaya konan, unutulmaya yüz tutsa da birtakım hafızalarda yer etmiş her türlü ögenin kente kazandırılması gereken bir değer olduğudur. Aslında küreselleşme sonucu kimliksizleşme, yereldeki değerlerin kaybolması sorunu her bölgede karşımıza çıkmaktadır. Tektipleşen konutlar, çok sık değiştirilen kent mekânları, restore edilmesi gereken tarihi alanların yıkılması vb. süreçler kentlileri yaşadıkları yere yabancılaştırmaktadır. Bu çalışmada da özellikle belleğin saptanmasına ilişkin sorularda, Denizli yerel mimarisi, kaybolmuş su varlığı ve kanalları, merdivenli sokakları, kale surları ya da Kaleiçi bölgesinin kullanıcılar tarafından yeterince vurgulanmadığı gözlemlenmektedir. Kentin tarihine ilişkin, bölgede hangi medeniyetlerin var 
olduğuna ilişkin ya da kent içinde kentin çevresinde bulunan antik kentlere referans olabilecek uygulama olmadığı için kolektif belleklerde boşluklar oluşmaktadır. Özellikle yaşça daha genç kullanıııların çevrelerine çok daha fazla yabancı oldukları ortaya çıkmaktadır. Oysa kolektif bellek sürdürülebilirliği açısından onların algılarının çok daha önemli olduğunu söylemek mümkündür.

Yapılan çalışmada elde edilen sonuçlardan biri de kişilerin antik kentlerde bulunup bulunmadığıdır. Buna göre Denizli Kenti'nde uzun yıllardır olup ancak antik kentlerde hiç bulunmamış olanların sayısı $\% 13,6$ 'dır. Yani Denizli kentlilerinin kentte yaşadığı ancak kentlerini yaşayamadığı bir durum söz konusudur. Kullanıııların kendi kentlerindeki antik kentleri ve dönemleri tanımamaları gerekli bilgilendirmelerin yapılmamasından da ileri gelebilmektedir. Antik kentlerin birbirlerini referans verecek nitelikte bir şekilde olması ilgiyi, bilgiyi ve turizmi artıracaktır. Bu alanların her biri kent için bellek mekânı niteliğindedir ve başta ulaşım olmak üzere her türlü ilişkilerinin sağlanması önemlidir. Tarihsel dokulara ve kültürel değerlere kent ve çevresi ile erişebilirliğinin sağlanması, okunabilirliği, tanınırlığı ve en önemlisi sürdürülebilirliğinin sağlanması ilk hedefler arasında olmalıdır.

Bunların yanı sıra kullanıcılardan, yaşadıkları şehre ilişkin örnekler verirken tanımladıkları kavramlar arasında kentsel kimlik bileşenlerindeki dört temel kategoriden hemen hemen tüm başlıklara ilişkin yorumlar alınmıştır. Sadece yapay çevre özelliklerinden donatı ölçeğinde hiçbir cevaba rastlanmamıştır. Bu da Denizli Kenti'nin donatı ölçeğinde endüstriyel tasarım ürünlerine yönelik akılda kalıcı, kimlik barındıran pek fazla örnek bulunmayışını ortaya koymaktadır.

Çalışmada, kullanıcıların daha çok vakit geçirdikleri alanların kent içindeki AVM'ler olduğu gözlemlenmiştir. Yeni kent merkezi olarak adlandırılan bu alanlarda Denizli kimliğini barındıran, toplumsal belleğe katkı sunacak en ufak bir öge bulunmamaktadır. İnsanlar bu alanlara her ne kadar sosyalleşme amaçlı gitseler de, daha çok tüketime teşvik edilen kimliksiz mekânlarda vakit geçirmiş olmaktadır. Aslında kişi kendini, kentinde değil de Türkiye'nin herhangi bir bölgesinde hissettiğinde, kimlik yoksunluğundan bahsetmek yanlış olmaz. Insanları bu birbirinin kopyalanmış alanlarından çekmek yerine, bu alanların da kent kimliğine uygun tasarlanması öncelikli olmalıdır.

Bir yere ait olma duygusu yaşamsal bir gerekliliktir. Aidiyet ve duyarlıık, toplumları çok daha güvenilir, yaşanılabilir, sağlıklı ve dolayısı ile kimlikli hale getirir. Planlama yapılırken, kullanııının anlam yüklediği her mekân, tarihi bir yer ya da unutulmayan bir değere dikkat edilmesi gerekir. Çünkü fiziksel her türlü müdahale sosyal düzeni de yakından etkiler. Bu bağlamda planlama ve tasarımcılara önemli sorumluluklar düşmektedir.

Özellikle tarihi çevrelerde, antik kentlerin birlikte yaşadığı modern kentlerde, kimlik korunması, aynı zamanda kent belleğini de oluşturduğundan, son zamanlarda bu konular üzerine çalışan pek çok meslek disiplini bulunmaktadır. Ülkemizde özellikle son yıllarda kentsel kültürel varlıklar hızla yok olmakta ve bu durum kentlerde yozlaşma ve kimlik değerlerinin yitirilmesine yol açmaktadır.

Kurulması milattan öncesine dayanan Denizli kentinin kolektif belleğine sahip çıkmak, aynı zamanda kentsel ve kültürel mirasa sahip çıkmak anlamına gelir. Sürekli bir değişim halinde olan küresel çevrede, toplumsal uyumdan, tarihten, kent bilincinden bahsetmek aynı hızla değişmektedir. Ancak yenilikçi çözümlerle farkındalık seviyesini yükseltmeye, kenti, kentliyi, tarihi dokuyu korumaya hiç olmadığı kadar ihtiyaç bulunmaktadır.

Sonuç olarak Denizli Kenti'ne hissedilen aidiyet duygularını artırmak ve kolektif bilince katkı sağlamak amacı ile çeşitli sosyal projeler ve fikir projeleri geliştirilmesi önemlidir. Özellikle tasarım yarışmaları, bölgede ayrıntılı araştırmalar gerektirecek ve bu fikirlerin gerçekleştirilmesi durumunda ise Denizli kent belleğine olumlu katkıları olacaktır. Kentin ruhunu önemseyen uygulamalar arttıkça insanların yaşadıkları çevreye ilişkin algıları da olumlu yönde gelişecektir.

\section{Teşekkür ve Bilgi Notu}

Makalede ulusal ve uluslararası araştırma ve yayın etiğine uyulmuştur. Çalışmada etik kurul izni, Pamukkale Üniversitesinin Sosyal ve Beşeri Bilimleri Bilimsel Araştırma ve Araştırma ve Yayın Etiği Kurulu'nun 27.10.2021 tarih ve 68282350/22021/G019 sayılı kararı ile alınmıştır. 


\section{Yazar Katkısı ve Çıkar Çatışması Beyan Bilgisi}

Makalede 1. yazar \% 60, 2. yazar \% 25, 3. yazar \% 15 oranında katkıda bulunmuştur. Herhangi bir çıkar çatışması bulunmamaktadır.

\section{Kaynaklar}

Aly, S.S.A. (2011). Modernization and regionalism: Approaches for sustainable revival of local urban identity. Procedia Engineering. 21,503-512, https://doi.org/10.1016/j.proeng.

Anonim. (2017). Denizli II Kültür ve Turizm Müdürlüğü, http://www.pamukkale.gov.tr/tr/ GenelBilgiler-Denizli/Daglar/Ovalar, Erişim Tarihi: 08.04.2017

Anonim. (2019). https://tr.wikipedia.org/wiki/Denizli. Erişim Tarihi: 06.07.2019.

Anonim. (2020a). https://tr.wikipedia.org/wiki/Denizli 27nin_il C3 A7eleri, Erişim Tarihi: 14.05.2020.

Anonim. (2020b). https://denizli.ktb.gov.tr/TR-211863/yasam-ve-ahilik.html

Aslan, S. ve Kiper, P. (2016). Kimlik ve bellek sorunu sarmalında kentler: Amasra Kenti örneğinde firsatlar ve tehditlerin değerlendirilmesi. Ideal Kent, vol. 7, no. 20, pp. 881-905.

Avcıoğlu, S. (2016). Tarihi çevrelerde kentsel koruma ve kentsel yenileme eğilimleri: yasal ve yönetsel çerçeve. Kent Araştırmaları Dergisi (Journal of Urban Studies). Issue 20, Volume 7. ISSN: 13079905. 698-719.

Avşar, Ö. B. (2014). Denizli geleneksel konut mimarisinin değişim sürecinin altıntop mahallesi örneğinde irdelenmesi. Artium, 2(2).

Baykara, T. (1994). Denizli- Türkiye Diyanet Vakfı İslam Ansiklopedisi. C.9. s. 155-159.

Bektaş, C., (2007). Denizli'nin Geleceği. Uluslararası Denizli ve Çevresi Tarih ve Kültür Sempozyumu Bildiriler Kitabı. PAU Fen Edebiyat Fakültesi Tarih Bölümü Yayınları 1. Denizli. 264-272.

Belge, R. (2018). Denizli kent kimliğini oluşturan coğrafi öğeler. Ege Coğrafya Dergisi 27 (2), 2018, 167181, İzmir-TÜRKIYE Aegean Geographical Journal, 27 (2), 2018, 167-181.

Bieling, C., Plieninger, T., Pirker, H. ve Vogle, C. R. (2014). Linkages between landscapes and human well-being: An empirical exploration with short interviews. Ecological Economics, 105 (2014) 1930.

Boyer, C. (1998). The City of Collective Memory. Cambridge: MIT Press.

Çalak, I. K. (2012). Kentsel ve kolektif belleğin sürekliliği bağlamında kamusal mekanlar: ULAP Platz Örneği, Almanya. Tasarım+Kuram Dergisi. Cilt 8, Sayı 13, s34-47.

Calvino, I. (1972). Görünmez Kentler. Yapı Kredi Yayınları. 19. Baskı; Syf:40.

Çelen Öztürk, A. (2016). Eskişehir'in geçmişteki ve bugünkü kent belleğinin zihin haritaları üzerinden okuma denemeleri. Idealkent, vol. 7, no. 20, pp. 856-880.

Çöl, Ş. (1998). Kentlerimizde Kimlik Sorunu Ve Günümüz Kentlerinin Kimlik Derecesini Ölçmek İçin Bir Yöntem Önerisi. Doktora Tezi. Mimar Sinan Üniversitesi Fen Bilimleri Enstitüsü, İstanbul.

Cuşa, H. (2013). Murathan Mungan'ın seçtikleriyle bir dersim hikayesinde kolektif bellek: Dersim. Tunceli Üniversitesi Sos. Bilim. Derg., vol. 2, no. 3, pp.89-98.

Erdoğan, G. ve Çorbacıoğlu Akay, S. (2018). Denizli Kent Kimliği Bileşenleri. Kent Akademisi | Kent Kültürü ve Yönetimi Hakemli Elektronik Dergi | Cilt: 11 Sayı: 3. Sayfa, 459-473.

Göregenli, M. (2010). Çevre Psikolojisi: İnsan-Mekân İlişkileri (1. Baskı). İstanbul: İstanbul Bilgi Üniversitesi Yayınları.

Halaç, H. H., Yıldırım, Ö. C. ve Kalak, M. (2018). Denizli Hulusi Oral evi yapısal bozulmalar ve koruma sorunları. AlFarabi Uluslararası Sosyal Bilimler Dergisi, 2(1), 11- 31.

Halbwachs, M. (1950). The Collective Memory [Chapter 4]. pp. 1-15. 
Hall, T. (2001). Urban geography. 2nd edition. Routledge.

Kaypak, Ş. (2010). Antakya'nın kent kimliği açısından irdelenmesi. Mustafa Kemal Üniversitesi Sosyal Bilimler Enstitüsü Dergisi, 7(14).

Kısakürek, Ş. ve Bayazıt, E. (2021). Kolektif bellek kentsel bellek ve mekânsal bileşenlerin kent kimliğindeki yeri: Kahramanmaraş Kenti örneği, Journal of Environmental and Natural Studies, Volume, 3, Issue 1, Pages, 1-21.

Kültür ve Turizm Bakanlığı, (2018). 2017 yılı Denizli müze ve ören yerleri ziyaretçi sayıları. https://denizli.ktb.gov.tr/

Kutay Karaçor, E. ve Köylü, P. (2019). Kentsel bellek ve fiziksel çevre kalitesi arasındaki ilişki. 1. Uluslararası Peyzaj Mimarlığı Kongresi Bildiriler Kitabı. Sf.162-170. ISBN: 978-605-01-1409-6.

Lalli, M. (1992). Urban related identity: theory, measurement and empirical findings. Journal of Environmental Psychology, 12, 285-303.

Lynch, K. (1960). The Image of the City, The M.I.T Press, Cambridge.

Mutlu, E., Tanrıverdi Kaya, A. ve Polat, H. (2019). Kent kimliğinin korunması ve kolektif bellek mekanlarının tespiti. Ileri Teknoloji Bilimleri Dergisi, Cilt 8, Sayı 2. ISSN:2147-3455.

Oğuz, M.Ö. ve Özkan, T.S. (2004). Kentler ve İmgeler. Gazi Üniversitesi Yayinlari. Ankara.

Othman, S., Nishimura, Y., and Kubota, A. (2013). Memory association in place making: A review. Procedia - Social and Behavioral Sciences, 85, 554-563.

Pèrouse, J. F. (2006). Kentsel bellek ve kent müzeleri: İstanbul şehri gözlem ve merkezi deneyimi Kentler ve Kent Müzeleri, Kent Müzeleri Uluslararası Sempozyumu, 21-22 Nisan 2006, 105-110. Antalya.

Perry, D. C. ve Liggett, H. (1995). Spatial practices: critical explorations in social/spatial theory. Sage Publications.

Proshanksy, H.M. (1978). The City and Self İdentity. Environment \& Behavior, 10(2), 147-170.

Rossi, A. (1960). The architecture of the city. Cambridge, MA: MIT Press.

Sağlık, E. ve Kelkit, A. (2019). Kentsel kimlik bileşenlerinin kent kullanıcıları tarafından belirlenmesi: Örnek kent Çanakkale. Çanakkale Onsekiz Mart Üniversitesi Fen Bilimleri Enstitüsü Dergisi. 5,1, 63-79.

Savaş Yavuzçehre, P. (2013). Küreselleşmenin artan etkisinde Denizli. Idealkent Kent Araştırmaları Dergisi, Küreselleşme ve Anadolu Kentleri, 8: 200-228.

Savaş Yavuzçehre, P. (2016). Üniversitelerin kentlerine etkileri: Denizli Pamukkale Üniversitesi örneği. Suleyman Demirel University The Journal of Faculty of Economics and Administrative Sciences Y.2016, Vol.21, No.1, pp.235-250.

Savaş Yavuzçehre, P. (2010). Kentsel mekân kullanımında değişim: Denizli Kenti örneği. Süleyman Ddemirel Enstitüsü. Sosyal Bilimler Enstitüsü. Doktora Tezi.

Saylan, S. (2016). Kent belleğinin sürekliliğinde kentsel artifaktların önemi: İstanbul Tarihi Yarımada 19. yüzyıl ızgara plan uygulamaları. Yıldız Teknik Üniversitesi, Fen Bilimleri Enstitüsü, Mimarlık Anabilim Dalı, Yüksek Lisans Tezi, 170s.

Selvi Ünlü, T. (2017). Kent kimliğinin oluşumunda kentsel bellek ve kentsel mekan ilişkisi: Mersin örneği. Planlama 2017;27(1):75-93.

TDK, (2020). Türk Dil Kurumu Sözlüğü. https://sozluk.gov.tr/

Tekeli, i. (1991). Bir Kentin Kimliği Üzerine Düşünceler. Kent Planlaması Konuşmaları, Ankara: TMMOB Mimarlar Odası Yayını, s. 79-89. 
Tekkanat, S. S. ve Türkmen, S. N. (2018). Tarih boyunca kent formlarının biçimlenişi üzerine bir inceleme. Aksaray Üniversitesi Iktisadi ve Idari Bilimler Fakültesi Dergisi. Yıl: 2018 Cılt: 10 Sayı: 4 107-124.

Topçu, K. (2011). Kent kimliği üzerine bir araştırma: Konya örneği. Uluslararası Insan Bilimleri Dergisi. Cilt:8 Sayı:2. ISSN:1303-5134.

Turan, S. ve Yalçıner Ercoşkun, Ö. (2017). Meydanlardaki isim değişikliklerinin kent belleğine etkisi: Ankara örneği. Mimarlık Bilimleri ve Uygulamaları Dergisi (MBUD), 2(1):55-68. e-ISSN: 25480170.

Uçman Altınışık, I. (2017). Arkeolojik ve endüstriyel kent Denizli'de PAÜ MTF Mimarlık Bölümü. Perspektifler 2017 Denizli Dosyası. Pamukkale Üniversitesi Yayınları. e ISBN: 978-975-6992-708. s7-12.

Zengin, M. (2017). Denizli kentinin bazı peyzaj değerlerine genel bir bakış. Perspektifler 2017 Denizli Dosyası. Pamukkale Üniversitesi Yayınları. e ISBN: 978-975-6992-70-8. s13-22. 